\title{
NAUKA JEZZYKA POLSKIEGO JAKO OBCEGO NA UNIWERSYTECIE MEDYCZNYM W LODZI. POTRZEBY STUDENTÓW W ŚWIETLE BADAŃ ANKIETOWYCH
}

\begin{abstract}
Słowa kluczowe: nauczanie języka polskiego jako obcego, polski język medyczny, potrzeby uczących się

Streszczenie. Artykuł przedstawia wyniki badań ankietowych przeprowadzonych wśród studentów Premedical Preparatory Course oraz studentów medycyny Uniwersytetu Medycznego w Łodzi. Celem badania było określenie potrzeb studentów uczestniczących w kursach języka polskiego jako obcego w Centrum Nauczania Języków Obcych Uniwersytetu Medycznego w Łodzi. Pytania dotyczyły oczekiwań wobec kursu, jego programu, częstotliwości zajęć oraz nauki elementów języka medycznego. Dodatkowo studenci przedstawili własne pomysły odnośnie do organizacji kursów języka polskiego.
\end{abstract}

Wśród cudzoziemców studiujących w Polsce największym zainteresowaniem cieszą się kierunki medyczne. „Od roku akademickiego 2004/2005 standardem stało się oferowanie programów anglojęzycznych przez polskie uczelnie medyczne" (Ławnicka-Borońska i in. 2011, s. 323). Wśród nich znajduje się również Uniwersytet Medyczny w Lodzi. Studenci medycyny, jak i ci przygotowujący się do podjęcia tego typu studiów uczęszczają na kurs języka polskiego odbywający się w Centrum Nauczania Języków Obcych Uniwersytetu Medycznego w Łodzi.

Lektorat języka polskiego jest obligatoryjnym przedmiotem w curriculum. Studenci przygotowujący się do podjęcia studiów medycznych uczęszczają na Premedical Preparatory Course. Obcokrajowcy uczą się tu języka polskiego w wymiarze 120 godzin. Jest to kurs obejmujący podstawy języka ogólnego. Na sześcioletnich studiach medycznych kurs języka polskiego to 100 godzin (na pierwszym i drugim roku po 50 godzin), a na studiach czteroletnich 50 godzin

*wojtczak.edyta@gmail.com, Uniwersytet Łódzki, Katedra Lingwistyki Stosowanej i Kulturowej, Wydział Filologiczny, Uniwersytet Łódzki, 90-236 Łódź, ul. Pomorska 171/173. 
(wyłącznie na pierwszym roku). Lektorat języka polskiego składa się z dwóch części: języka ogólnego i elementów języka medycznego. Warto przypomnieć, że język specjalistyczny to „dyskurs osób, które łączy posiadanie tej samej specjalizacji zawodowej, pełnienie tej samej funkcji lub zajmowanie tego samego stanowiska pracy" (Gębka-Wolak 2011, s.302). Zatem poznanie elementów języka medycznego ma na celu ułatwienie komunikacji w szpitalach. Studenci są tu przygotowywani do porozumiewania się zarówno w formie ustnej, jak i pisemnej.

\section{CEL BADANIA I METODA BADAWCZA}

Jednym z zagadnień związanych z nauką języka polskiego, w tym przypadku przez cudzoziemców studiujących kierunki medyczne, jest opracowanie programu nauczania zgodnie z potrzebami językowymi uczestników kursu. „Należy zaplanować proporcjonalnie do czasu trwania kursu odpowiednią liczbę godzin zajęć dominujących - kierunkowych oraz innych im towarzyszącym" (Janowska 2006, s. 158). W artykule przedstawiam wyniki badań, których celem było uzyskanie informacji na temat potrzeb studentów uczestniczących w lektoracie języka polskiego jako obcego na Uniwersytecie Medycznym w Lodzi.

Pomysł skoncentrowania się na oczekiwaniach słuchaczy kierunków medycznych to wynik zgłaszanych przez nich wątpliwości względem organizacji procesu nauczania. Zbieranie danych rozpoczęłam od pilotażu eksploracyjnego, którego celem była konceptualizacja problemu badawczego. Jak stwierdza A. M. Oppenheim (2004) polegać on może na długich, nieskonstruowanych wywiadach czy też rozmowach z najważniejszymi informatorami. W przypadku moich badań byli nimi obcokrajowcy uczestniczący w kursach języka polskiego, z którymi przeprowadzałam rozmowy w celu poznania ich opinii na temat wprowadzania języka medycznego podczas lektoratu. Zebrane w ten sposób informacje stały się podstawą do rozpoczęcia właściwych badań ankietowych (Wilczyńska, Michońska-Stadnik 2010, s.167). Warto wspomnieć, że autorami części pytań byli moi rozmówcy. Ankietyzacja została przeprowadzona za pośrednictwem Internetu. Udział w niej był anonimowy i dobrowolny. Ankieta (zob. aneks) zawierała pytania dotyczące m.in. wieku i pochodzenia respondentów (metryczka), organizacji kursu języka polskiego (liczba godzin, częstotliwość zajęć) oraz obecności elementów języka medycznego w programie nauczania (dolegliwości, na które mogą uskarżać się pacjenci, sposób przeprowadzania wywiadu lekarskiego, nazwy części ciała i narządów wewnętrznych, nazwy personelu medycznego oraz sprzętów szpitalnych). 


\section{CHARAKTERYSTYKA BADANEJ GRUPY}

Ankiety wypełniło pięćdziesięcioro studentów Uniwersytetu Medycznego w Lodzi, zarówno z Premedical Preparatory Course, jak i medycyny.

Studenci z Arabii Saudyjskiej byli najliczniejszą grupą, która wzięła udział w badaniu. Stanowili oni $44 \%$ ankietowanych. Respondenci z Kanady i Nigerii odpowiednio po 6\%. Następnie: Afganistan, Iran, Norwegia, Niemcy i Szwecja po $4 \%$, a pozostałe po $2 \%{ }^{1}$.

Respondentów w wieku 20 i 19 lat było najwięcej-odpowiednio 22\% i 20\%. Cudzoziemcy w wieku 23 lat stanowili 14\%, a w wieku 21 lat - 10\%. Żadna z pozostałych grup wiekowych nie przekroczyła $10 \%$.

Wśród ankietowanych liczną grupą okazali się cudzoziemcy uczestniczący w Pedemical Preparatory Course. Stanowili oni 50\%. Studentów z pierwszego roku było $18 \%$, z drugiego i trzeciego po $12 \%$. Natomiast z czwartego roku $8 \%$. Nikt z piątego i szóstego roku studiów nie wziął udziału w badaniu.

Wszyscy studenci biorący udział w badaniu ankietowym zadeklarowali znajomość języka angielskiego. Kolejnym równie popularnym językiem okazał się język arabski (na co wskazuje duża liczba respondentów z krajów arabskich). Inne języki to te, którymi cudzoziemcy posługują się w swoich krajach, m.in.: język perski w Iranie, język portugalski w Brazylii, języki: dari i paszto w Afganistanie, język malajski w Malezji, język turecki w Turcji². Trzydzieści dwie osoby (64\%) zadeklarowały również, że posługują się językiem polskim. Spośród nich najwięcej było tych na poziomie A1 - 15 osób (47\%). Należy wspomnieć, że pozostałe 19 osób oceniło, że w ogóle nie mówi po polsku. Dziewięć z nich to uczestnicy Premedical Preparatory Course, którzy uczą się polskiego około pół roku, a pozostałe dziesięć to studenci medycyny. Świadczy to o niskiej znajomości języka polskiego przez ankietowanych.

Prawie wszyscy studenci uczyli się lub obecnie uczą się języka polskiego wyłącznie na kursach prowadzonych przez Centrum Nauczania Języków Obcych Uniwersytetu Medycznego w Łodzi. Tylko trzy osoby uczestniczyły w innych kursach. Jedna wprowadzonym przez Uniwersytet Łódzki, jeszcze przed rozpoczęciem studiów na Uniwersytecie Medycznym w Łodzi. Pozostałe dwie uczestniczą w zajęciach indywidualnych.

Większość studentów zaznaczyła, że studiując w Polsce odczuwa potrzebę uczestnictwa w kursie języka polskiego. Dziewięcioro respondentów (12\%) nie widzi takiej potrzeby i wolałoby w nim nie uczestniczyć.

\footnotetext{
${ }^{1}$ Pozostali respondenci pochodzili z: Iraku, Irlandii, Malezji, Pakistanu, Papui Nowej Gwinei, Polski, Szwecji, Turcji, USA, Zambii, Brazylii i Kanady.

${ }^{2}$ Wśród wymienionych języków dodatkowo znalazły się: afrikaans, bośniacki, farsi, francuski, hindi, hiszpański, holenderski, irlandzki, niemiecki, norweski, portugalski, punjabi, szwedzki, urdu (kolejność alfabetyczna).
} 


\section{WYNIKI ANKIET}

\subsection{OCZEKIWANIA STUDENTÓW PRZEZ ROZPOCZECCIEM KURSU JĘZYKA POLSKIEGO}

Studenci zostali zapytani o oczekiwania, które mieli wobec kursu języka polskiego jeszcze przed jego rozpoczęciem. Trzynaścioro cudzoziemców wspominało o swoich obawach związanych z nauką języka polskiego, który w ich odczuciu jest bardzo trudny. Ankietowani zgodnie potwierdzili, że ich przypuszczenia się sprawdziły. To właśnie w większości studenci z Premedical Preparatory Course skupiali się na trudności języka, którego będą się uczyć. Równie popularną odpowiedzią był brak jakichkolwiek oczekiwań (dziesięcioro respondentów).

Kolejną rzeczą, której spodziewali się studenci przed przystąpieniem do kursu języka polskiego było nabycie umiejętności pozwalających uczestniczyć w codziennej komunikacji z rodzimymi użytkownikami języka polskiego (ośmioro ankietowanych). Opinia ta była najpopularniejsza wśród studentów pierwszego i trzeciego roku.

\subsection{OPINIA O KURSIE PO JEGO ROZPOCZĘCIU}

Studenci zwrócili uwagę na zbyt małą ilość czasu poświęcaną zwykle się na praktyczne użycie poznanego materiału językowo-gramatycznego oraz na niewystarczającą liczbę zajęć. Respondenci chcieliby również uczyć się wyłącznie niezbędnych rzeczy, które umożliwiałyby im podstawową komunikację w sytuacjach dnia codziennego. Spowodowane jest to wieloma obowiązkami związanymi ze studiami medycznymi, a więc z brakiem czasu, który mogą poświęcić na naukę języka polskiego. Podkreślali również, że w dłuższej perspektywie chcieliby mówić płynnie po polsku. Dobre podstawy umożliwiłyby im dalszą naukę.

Studenci, którzy uczestniczą w lektoracie języka polskiego, jak i ci, którzy już go ukończyli, zwrócili uwagę, że na kursie brakuje praktyki językowej. Sugerowali, aby zrezygnować z części zagadnień gramatycznych, których w ich odczuciu jest za dużo, a więcej uwagi poświecić na konwersacje. Czas spędzony na ćwiczeniu w praktyce nabytych umiejętności w obecności lektora umożliwiłby szybkie otrzymanie informacji zwrotnej dotyczącej podejmowanych prób komunikacji w języku polskim. W opinii respondentów przy obecnej liczbie godzin przeznaczonych na kurs języka polskiego należałoby zmniejszyć zakres zagadnień gramatycznych. 
Z przedstawionych opinii wynika, że w przekonaniu uczestników zajęć program kursu języka polskiego należałoby zmodyfikować w taki sposób, aby możliwie jak najwięcej czasu poświęcić praktyce językowej. Warto byłoby wprowadzić zajęcia, w czasie których odbywałyby się wyłącznie konwersacje. Równie istotne jest zweryfikowanie i wybranie najistotniejszych zagadnień zarówno gramatycznych, jak i leksykalnych. Związane jest to z napiętym programem studiów, a w związku z tym brakiem czasu, który studenci mogliby poświęcić nauce. Natomiast ewentualne zwiększenie liczby godzin języka polskiego, nie powinno wiązać się z poszerzeniem zakresu materiału, a jedynie z formą zajęć: konwersacje, symulacje, odgrywanie ról z życia codziennego.

\subsection{LICZBA GODZIN, TYGODNIOWY ROZKŁAD ZAJĘĆ I ROLA LEKTORA}

Studenci zapytani o to, czy liczba godzin języka polskiego przewidziana dla poszczególnych kursów jest wystarczająca, w 50\% odpowiedzieli twierdząco i według nich nie ma potrzeby jej zmieniać. Dziewiętnaście osób, czyli 38\% badanej grupy opowiedziało się za zwiększeniem liczby godzin. Natomiast tylko jedna osoba za ich zmniejszeniem. $8 \%$ ankietowanych nie wyraziło żadnej opinii.

Następnie uczący się zostali zapytani o to, czy chcieliby mieć codziennie trwającą 45 minut lekcję języka polskiego. Większość ankietowanych oceniła pozytywnie ten pomysł. Było to $66 \%$ ankietowanych. Propozycja ta spotkała się z pozytywnym odbiorem wśród większości studentów Premedical Preparatory Course, jak i każdego kolejnego roku studiów medycznych. Uczący się wspominali, że takie rozwiązanie pozwoliłoby regularnie powtarzać materiał oraz uczyć się w efektywniejszy sposób. Studenci sugerowali, że dzięki temu lekcje byłyby ciekawsze i z pewnością skupienie się oraz zapamiętywanie okazałyby się łatwiejsze niż w przypadku kilku godzin lekcji języka polskiego naraz. Pojawiła się również opinia, że takie rozwiązanie byłoby dobre, ale nie jako obligatoryjne. Decyzję o uczestnictwie w takim kursie każdy student miałby podjąć indywidualnie. Jedna osoba zaznaczyła, iż mimo że jest to jej zdaniem dobry pomysł, to w praktyce mogłoby się okazać to trudne ze względu na napięty plan zajęć i na codzienne dojazdy do Centrum Nauczania Języków Obcych. Jedna osoba zaproponowała, by lekcja zamiast 45 minut, trwała 60 minut.

Przeciwko codziennym lekcjom opowiedziało się $26 \%$ respondentów. Ankietowani wspominali, że nie byłoby to możliwe ze względu na zbyt dużą liczbę innych zajęć. Obawiano się również, że codzienne lekcje mogłyby okazać się nudne, a materiał by się powtarzał. Wskazano, że uczący się potrzebują więcej kontaktu z innymi rodzimymi użytkownikami języka polskiego niż z polskim lek- 
torem oraz że mogłoby to być dobre rozwiązanie, ale wyłącznie dla osób planujących zostać po studiach w Polsce. Jedna osoba w ogóle nie ustosunkowała się do powyższej propozycji.

Studenci zostali zapytani o to jak często chcieliby mieć lekcje języka polskiego. 30\% zadeklarowało, że trzy razy w tygodniu. Za lekcjami dwa razy w tygodniu opowiedziało się $25 \%$, a codziennie chciałoby mieć lekcje $19 \%$ badanych.

Najczęściej pojawiające się odpowiedzi potwierdzają potrzebę zwiększenia częstotliwości zajęć na rzecz ich skrócenia. Respondenci zasugerowali, że lekcje języka polskiego powinny odbywać się rano, tak by „zaczynać dzień z językiem polskim”.

Uczący się zwrócili również uwagę na rolę, jaką pełnią lektorzy. Podkreślono, że dzięki ich odpowiedniemu przygotowaniu i właściwym sposobie tłumaczenia, opanowanie pewnych trudnych zagadnień okazało się prostsze. Dodatkowo, nauczyciele prowadzący kurs oprócz języka przekazują wiedzę na temat polskiej kultury, co może być przydatne w codziennym życiu.

\subsection{ELEMENTY JĘZYKA MEDYCZNEGO NA KURSIE JĘZYKA POLSKIEGO}

Ankietowani zapytani o to gdzie ich zdaniem język polski może okazać się przydatny w $43 \%$ wskazali na miejsce ich pracy, czyli szpital. To tutaj ich zdaniem jego znajomość może okazać się niezbędna, ponieważ większość pacjentów nie mówi w języku angielskim. Kolejne 34\% wskazało na codzienne życie w Polsce. 10\% nie widzi potrzeby nauki języka polskiego, a 13\% w ogóle się nie ustosunkowała do zadanego pytania. Niemniej jednak $77 \%$ badanych uważa, że język polski jest im bardzo potrzeby i należy go po prostu znać, przynajmniej na poziomie podstawowym.

Badana grupa studentów widzi potrzebę nauki języka medycznego. Ma to związek z sytuacjami, z którymi spotykają się w szpitalach ankietowani studenci. Często znajomość języka polskiego jest od nich wymagana przez personel szpitalny oraz pacjentów. Jeden $\mathrm{z}$ ankietowanych dodał, że od kiedy nauczył się języka polskiego w stopniu komunikacyjnym, pełni funkcję ,ttumacza” między pacjentami a innymi zagranicznymi studentami.

W związku z powyższym ważnym celem moich badań była ocena zapotrzebowania studentów na kurs języka polskiego z elementami języka medycznego. Jak się okazało ankietowani widzą potrzebę nauki języka polskiego właśnie w związku z zajęciami w szpitalach, a co za tym idzie w kontakcie z pacjentami i personelem szpitalnym.

Każdy ankietowany został zapytany, czy język medyczny pojawiał się na kursie, w którym uczestniczył. Pytanie dotyczyło zarówno studentów medycyny, 
dla których przewidziano elementy tej odmiany języka polskiego, jak i uczestników Premedical Preparatory Course.

Obecność elementów medycznej odmiany języka polskiego w czasie nauki języka polskiego w Centrum Nauczania Języków Obcych zadeklarowało 62\% uczących się. Warto wspomnieć, że 35\% z nich stanowili studenci Premedical Preparatory Course, dla których język medycznych nie jest w programie obowiązkowy. 34\% ankietowanych odpowiedziało, że w czasie studiów nie uczestniczyli w zajęciach, na których wprowadzałoby tego rodzaju materiał. Wśród nich $35 \%$ to osoby studiujące już medycynę. Odpowiedzi nie udzieliło $4 \%$ badanych. Byli to studenci kursu przygotowawczego.

Ankietowani zostali zapytani o to, jaką część kursu, w którym uczestniczą, powinien ich zdaniem stanowić język medyczny. Od odpowiedzi wstrzymało się $22 \%$ badanych. 55\% z nich to studenci Premedical Preparatory Course. 21\% uczących się wskazało, że elementy języka medycznego powinny wypełniać połowę kursu. Wszyscy są obecnie studentami medycyny. Kolejne $18 \%$ ankietowanych zaproponowało, by było to $40 \%$ kursu, a $10 \%$ odpowiedzi wskazywało na $60 \%$. Stąd wniosek, że większość studentów widzi potrzebę nauki języka medycznego na kursie języka polskiego prowadzonym przez Centrum Nauczania Języków Obcych. Jak pokazują wyniki badań, miałby on zajmować połowę kursu.

Studenci Premedical Preparatory Course zapytani o to, czy już w czasie tego kursu powinni być przygotowywani pod względem umiejętności językowych do pracy w środowisku medycznym, w $66 \%$ procentach odpowiedzieli twierdząco. $22 \%$ nie widzi takiej potrzeby, a $12 \%$ w ogóle nie odpowiedziało na to pytanie.

Następnie ankietowani zostali zapytani o to, co powinien zawierać taki kurs. Wyniki przedstawia tabela:

Tabela 1. Zagadnienia, które powinny pojawić się na kursie

\begin{tabular}{|l|c|c|c|}
\hline \multirow{2}{*}{ Zagadnienie } & \multicolumn{2}{c|}{ Odpowiedź (w \%) } \\
\cline { 2 - 4 } & Tak Nie & 3 & Nie wiem \\
\hline Sposoby komunikowania się z pacjentami & 87 & 5 & 8 \\
\hline Objawy chorób & 87 & 3 & 7 \\
\hline Nazwy części ciała & 90 & 26 & 12 \\
\hline Nazwy narządów wewnętrznych & 62 & 33 & 20 \\
\hline Wypisywanie recept & 49 & 31 & 10 \\
\hline Nazwy urządzeń i maszyn w szpitalu & 49 & 8 & 18 \\
\hline Nazwy członków personelu medycznego & 82 & \multicolumn{2}{c|}{} \\
\hline
\end{tabular}


Z powyższych danych wynika, że studenci zdecydowanie widzą potrzebę nabywania umiejętności pozwalających im na sprawne komunikowanie się $\mathrm{w}$ szpitalu, opisywanie symptomy chorób, nazywanie części ciała, narządy wewnętrzne i pracowników szpitala. Prawie połowa chciałaby nabyć umiejętności w zakresie wypisywania recept oraz nazwania narządów wewnętrznych i urządzeń szpitalnych.

\subsection{UWAGI I SUGESTIE STUDENTÓW MEDYCYNY}

Ostatnią częścią moich badań była ocena kursów języka polskiego przez studentów medycyny, a więc przez studentów, którzy mieli już kontakt z pacjentami i personelem medycznym, a co za tym idzie mają już za sobą doświadczenia związane $\mathrm{z}$ komunikacją $\mathrm{w}$ języku polskim w środowisku medycznym.

Przede wszystkim studenci ci uważają, że ich znajomość języka polskiego jest niewystarczająca. Stwierdziło tak $91 \%$ ankietowanych. Za źródło problemów uważają przede wszystkim brak praktyki oraz zbyt wiele różnych zagadnień w stosunku do liczby godzin języka polskiego.

Studenci medycyny potwierdzili, że znajomość języka polskiego jest im potrzebna zarówno na co dzień, jak i w szpitalu. 71\% zwróciło uwagę, że miało problemy $\mathrm{z}$ komunikacją $\mathrm{w}$ języku polskim $\mathrm{w}$ szpitalu. Trudności pojawiały się przede wszystkim w czasie rozmów z pacjentami, zarówno podczas zbierania wywiadu lekarskiego, jak i w sytuacjach, gdy pacjenci zadawali pytania. Dodatkowo ankietowani mieli problemy podczas rozmów z personelem szpitalnym: lekarzami i pielęgniarkami oraz z nazywaniem różnego rodzaju narzędzi i urządzeń. Studenci ponownie zwracali uwagę na potrzebę ćwiczenia umiejętności komunikacyjnych, ponieważ często nawet jeśli rozumieją skierowaną do nich wypowiedź, to mają problemy ze sformułowaniem odpowiedzi.

Pojawiały się sugestie, by kurs języka polskiego obejmował również kolejne lata studiów, co pozwoliłoby kształtować umiejętności komunikacyjne cały czas. Uwagi dotyczyły też liczebności grup. Ich zdaniem zmniejszenie liczby osób w grupach pozytywnie wpłynęłoby na efektywność nauki. Zaproponowano również, by kursy przewidywały projekty studenckie realizowane poza uczelnią, „co jest charakterystyczne dla amerykańskich i kanadyjskich uniwersytetów" (fragment wypowiedzi z ankiety). Wspomniano również o stworzeniu możliwości nauki dla studentów, którzy mają problem z porozumiewaniem się w języku angielskim lub z językiem polskim. Mogłyby to być grupy studentów cudzoziemskich pomagających sobie nawzajem lub też spotkania z polskimi studentami. Wpłynęłoby to na polepszenie umiejętności językowych słabszych studentów i jednocześnie umożliwiłoby poznanie rówieśników, z czym zagraniczni studenci miewają problemy. 


\section{PODSUMOWANIE}

Z przedstawionych powyżej wyników przeprowadzonych przeze mnie badań ankietowych można wnioskować, że studenci medycyny widzą potrzebę zmodyfikowania kursów języka polskiego w Centrum Nauczania Języków Obcych Uniwersytetu Medycznego w Łodzi. Przedstawione sugestie i uwagi dotyczą zagadnień omawianych na lekcjach, liczby godzin języka polskiego i odpowiedniego rozmieszczenia ich w rozkładzie zajęć oraz nauki elementów języka medycznego. Studenci zaproponowali również kilka rozwiązań, które pomogłyby w praktycznej nauce języka polskiego.

Warto zaznaczyć, że studenci nie ocenili negatywnie kursów języka polskiego proponowanych przez Centrum Nauczania Języków Obcych. Zasugerowali jedynie pewne zmiany, które pozytywnie wpłynęłyby na efektywność nauki. Badania ankietowe ocenili bardzo pozytywnie odbierając to jako wyjście naprzeciw oczekiwaniom studentów.

Mam nadzieję, że przedstawione przeze mnie wnioski okażą się przydatne w tworzeniu kolejnych programów dla uczestników Premedical Preparatory Course oraz studentów medycyny. Uważam, że wymaga to jednak kolejnych i bardziej szczegółowych badań, a w przypadku elementów języka medycznego, przede wszystkim konsultacji ze specjalistami, ponieważ to właśnie oni tworzą ten język specjalistyczny na potrzeby komunikacji profesjonalnej w obrębie własnej wspólnoty (Grucza 2007, s. 38).

\section{BIBLIOGRAFIA}

Gębka-Wolak M., 2011, Przygotowanie lektorów do nauczania języka specjalistycznego, w: K. Pluskota, K. Taczyńska (red.), Nowe perspektywy w nauczaniu języka polskiego jako obcego II, Toruń, s. 303-320.

Grucza S., 2007, Od lingwistyki tekstu do lingwistyki testu specjalistycznego, Warszawa.

Janowska I., 2006, Przygotowanie kursu językowego - programy nauczania, w: E. Lipińska, A. Seretny (red.), Z zagadnień dydaktyki języka polskiego jako obcego, Kraków, s. 155-175.

Ławnicka-Borońska M., Rudnik W. A., Wiśniewska J., 2011, Kurs języka polskiego jako obcego dla studentów medycyny, w: K. Pluskota, K. Taczyńska (red.), Nowe perspektywy w nauczaniu języka polskiego jako obcego II, Toruń, s. 321-331.

Oppenheim A. M., 2004, Kwestionariusze, wywiady, pomiary postaw, Poznań.

Wilczyńska W., Michońska-Stadnik A., 2010, Metodologia badań w glottodydaktyce. Wprowadzenie, Kraków. 


\section{ANEKS}

1. Pytania w języku angielskim

\begin{tabular}{|c|c|c|}
\hline \multicolumn{3}{|l|}{ 2. Age } \\
\hline 3. The student's present year of studies & \multicolumn{2}{|c|}{$\square$ Premedical Course $\square$ 1st $\square$ 2nd $\square$ 3rd $\square$ 4th $\square$ 5th $\square$ 6th } \\
\hline \multicolumn{3}{|l|}{ 4. Which languages do you speak? } \\
\hline \multicolumn{3}{|l|}{ 5. When did you come to Poland? } \\
\hline \multicolumn{3}{|c|}{ 6. How long have you been learning Polish? } \\
\hline 7. Are you currently studying Polish? & \multicolumn{2}{|l|}{$\square$ Yes $\square$ No } \\
\hline 8. Where? & \multicolumn{2}{|l|}{$\square$ Private lessons $\square$ Language school } \\
\hline \multicolumn{3}{|l|}{ What type of a course? } \\
\hline 9. How would you describe your level of Polish? & \multicolumn{2}{|c|}{$\square$ non-Polish speakers $\square$ A1 $\square$ A2 $\square$ B1 $\square$ B2 $\square$ C1 $\square$ C2 } \\
\hline \multicolumn{3}{|c|}{ 10. What were your expectations for the course of Polish before it started? } \\
\hline \multicolumn{3}{|c|}{ 11. Were your expectations met? If no, why? What Gould sou change? } \\
\hline \multicolumn{3}{|c|}{ 12. Do you think that you need Polish language course? } \\
\hline \multicolumn{3}{|c|}{ 13. Do you think that present number of hours is sufficient? If not, should they be extended or narrowed? } \\
\hline \multicolumn{3}{|c|}{ 14. Do you think that 45 -minute Polish lesson everyday is a good idea? Why? } \\
\hline \multicolumn{3}{|c|}{ 15. How many times should you have Polish lessons a week? How long lesson? } \\
\hline \multicolumn{2}{|c|}{ 16. Did you have/Do you have any elements of medical language during the course? } & $\square$ Yes $\square$ No \\
\hline \multicolumn{3}{|c|}{ 17. What percentage of the course should be devoted to the elements of medical language? } \\
\hline \multicolumn{2}{|c|}{ 18. Should the premedical course prepare you to a job in medical environment? } & $\square$ Yes $\square$ No $\square$ I don't know \\
\hline \multicolumn{2}{|c|}{ 19. If yes, do you think that the course should cover following elements: } & $\square$ Yes $\square$ No $\square$ I don’t know \\
\hline \multicolumn{2}{|c|}{ a) how to communicate with patients ( doctor - patient conversation) } & $\square$ Yes $\square$ No $\square$ I don't know \\
\hline \multicolumn{2}{|c|}{ b) symptoms that patients may suffer from } & $\square$ Yes $\square$ No $\square$ I don’t know \\
\hline \multicolumn{2}{|l|}{ c) body parts } & $\square$ Yes $\square$ No $\square$ I don’t know \\
\hline \multicolumn{2}{|l|}{ d) internal organs } & $\square$ Yes $\square$ No $\square$ I don't know \\
\hline \multicolumn{2}{|l|}{ e) how to write medical prescriptions } & $\square$ Yes $\square$ No $\square$ I don't know \\
\hline \multicolumn{2}{|c|}{ f) names of machines used in a hospital } & $\square$ Yes $\square$ No $\square$ I don't know \\
\hline \multicolumn{2}{|c|}{$\begin{array}{l}\text { g) titles of staff members in a hospital, for example: nurse, pharmacist and so } \\
\text { on }\end{array}$} & $\square$ Yes $\square$ No $\square$ I don't know \\
\hline \multicolumn{3}{|l|}{ h) Your suggestions } \\
\hline 20 Do you think that you will use Polish & ing your studies? Ifyes, where? & \\
\hline Place for your comments and suggestion & & \\
\hline FOR MEDICAL STUDENTS: & & \\
\hline 1. Is your knowledge of Polish sufficien & & $\square$ Yes $\square$ No \\
\hline 2. If not, why? Where is the problem? & & \\
\hline 3. In what situations do you use Polish? & & \\
\hline 4. What would you change in the preme & 1 course? Do you consider it to be useful & How? \\
\hline 5. How would you estimate Polish cour & fered at the university (number of hours, & contents)? \\
\hline 6. Have you ever had problems to comn & cate in Polish at the hospital? & $\square$ Yes $\square$ No \\
\hline 7. If yes, when? What kind of problem & you have? & \\
\hline Place for your comments and suggestion & & \\
\hline
\end{tabular}




\section{Pytania w języku polskim}

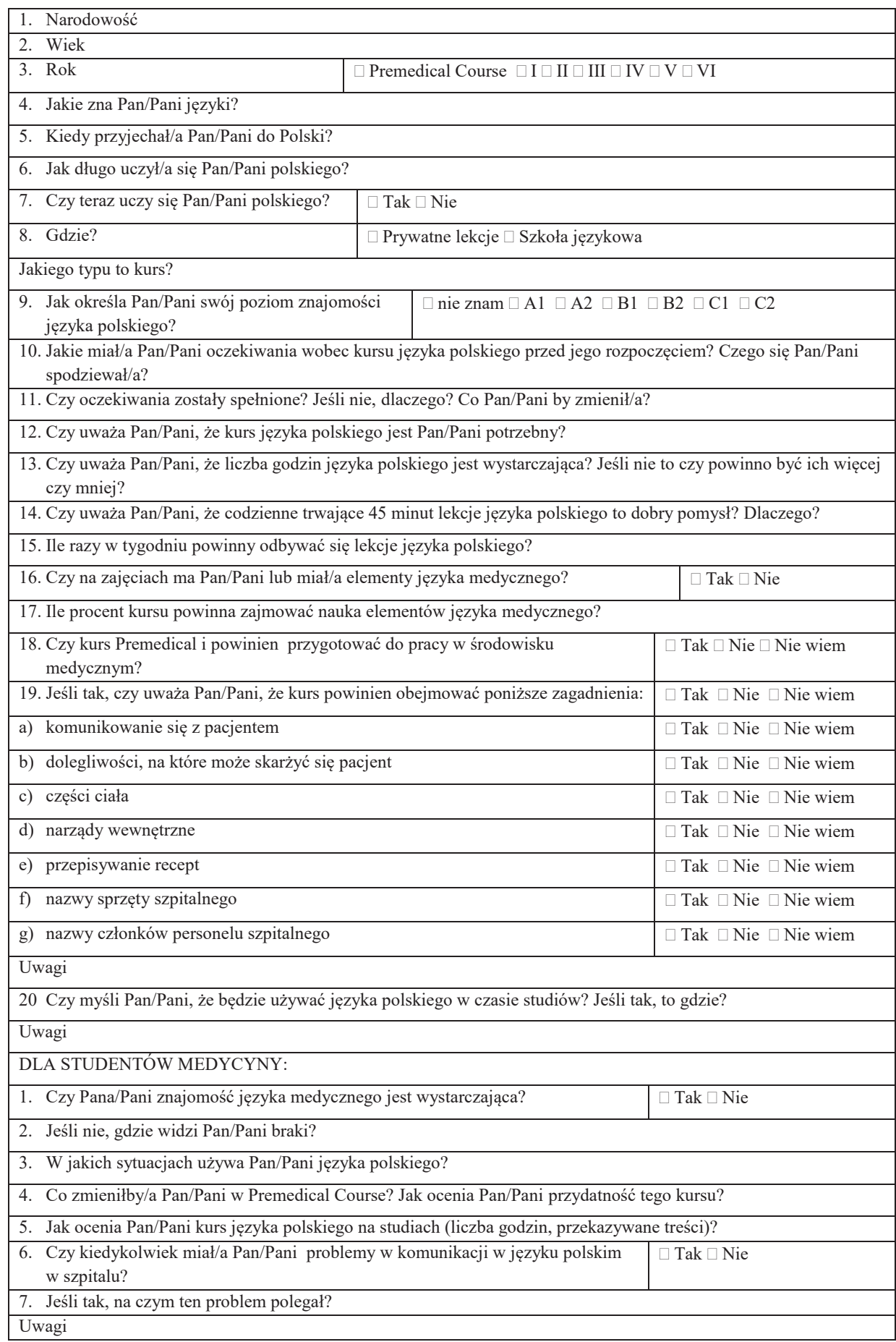


Edyta Wojtczak

\section{LEARNING POLISH AS A FOREIGN LANGUAGE AT THE MEDICAL UNIVERSITY OF LODZ. THE NEEDS OF STUDENTS IN THE LIGHT OF THE SURVEY}

Keywords: teaching Polish as a foreign language, elements of medical terminology, survey

Summary. The article discusses results of the survey conducted among students of Premedical Preparatory Course and students of medicine from Medical University of Lodz. The aim of the survey is to describe needs ofstudents participating in courses of Polish as a foreign language in Foreign Language Centre of Medical University of Lodz. Questions are related to the student's expectations toward the course, its programme, class frequency and learning elements of medical terminology. Additionally, the students present their own ideas concerning the organisation of Polish language courses. 